IZA DP No. 371

Rates of Return to Education: The View of Students in Switzerland

Stefan C. Wolter

André Zbinden

September 2001 


\title{
Rates of Return to Education: The View of Students in Switzerland
}

\author{
Stefan C. Wolter \\ Swiss Coordination Centre for Research in Education (SKBF), \\ University of Berne and IZA, Bonn \\ André Zbinden \\ Department of Economics, University of Berne
}

Discussion Paper No. 371

September 2001

\author{
IZA \\ P.O. Box 7240 \\ D-53072 Bonn \\ Germany \\ Tel.: +49-228-3894-0 \\ Fax: +49-228-3894-210 \\ Email: iza@iza.org
}

This Discussion Paper is issued within the framework of IZA's research area The Future of Work. Any opinions expressed here are those of the author(s) and not those of the institute. Research disseminated by IZA may include views on policy, but the institute itself takes no institutional policy positions.

The Institute for the Study of Labor (IZA) in Bonn is a local and virtual international research center and a place of communication between science, politics and business. IZA is an independent, nonprofit limited liability company (Gesellschaft mit beschränkter Haftung) supported by the Deutsche Post AG. The center is associated with the University of Bonn and offers a stimulating research environment through its research networks, research support, and visitors and doctoral programs. IZA engages in (i) original and internationally competitive research in all fields of labor economics, (ii) development of policy concepts, and (iii) dissemination of research results and concepts to the interested public. The current research program deals with (1) mobility and flexibility of labor markets, (2) internationalization of labor markets and European integration, (3) the welfare state and labor markets, (4) labor markets in transition, (5) the future of work, (6) project evaluation and (7) general labor economics.

IZA Discussion Papers often represent preliminary work and are circulated to encourage discussion. Citation of such a paper should account for its provisional character. 


\section{ABSTRACT}

\section{Rates of Return to Education: The View of Students in Switzerland*}

Wage expectations are important determinants for individual schooling decisions. However, research on individual expectations of students is scarce. The paper presents the Swiss results of a survey that was conducted in 10 European countries. Its main findings are that point estimates of wages after graduation are close to actual wages, whereas the expectations of the wage gain in the first ten years of professional experience exceed the actual wage gains significantly. While most of the deviation of individual expectations from actual wages can not be explained, we find that rates of return to education that are calculated on the base of individual wage and cost expectations as well as individual time preferences can be explained partially by the seniority of students, the self-perception of their academic performance and their subjective job perspectives. The high degree of unexplained heterogeneity in individual expectations and the differences between groups of students show the necessity to analyse the question further with bigger and more representative samples.

JEL Classification: $\quad$ C81, I20, J24, J31

Keywords: $\quad$ Rates of return to education, wages, expectations

Stefan C. Wolter

Swiss Coordination Centre for Research in Education

Entfelderstrasse 61

$\mathrm{CH}-5000$ Aarau

Switzerland

Tel.: + 41628352390

Fax: + 41628352399

Email: stefanwolter@yahoo.de

\footnotetext{
* The authors thank Rudolf Winter-Ebmer for the provision of the questionnaire as well as for the data compilation, bsef Zweimüller for providing the data from the University of Zurich. Bernhard A. Weber for his assistance and Rainer Winkelmann for helpful advice. The usual disclaimer applies.
} 


\section{Rates of Return to Education: The View of Students in Switzerland}

\section{Introduction}

"The expected earnings and other returns expected from education over the life cycle when related to cost, as they are in expected rates of return, are of great interest primarily because of their strong influence on student and family decisions about types and amount of education students seek to acquire” (Mc Mahon 1987, p. 187).

Studies about individual earnings or wage expectations are, although of widely recognised importance, scarce in economic literature. As a part of the European Project on the Rates of Return to Education in 15 European Countries, PURE ${ }^{\square}$, researchers from 10 countries collected information on wage expectations of University students in different fields of study (see Brunello et al. 2001). The present paper goes into the details of the Swiss data gathered in this project and extends the analysis to the question of rates of return to education by constructing individual life-earnings profiles of the interviewees.

\section{A short review of the literature}

The literature of these kind of empirical investigations of individual expectations was almost entirely American for a long time (with the exception of Dolton and Makepeace 1990). Most recently a few researchers have tried to replicate the US studies in Europe. The known studies differ considerably in respect to the methods applied to find out about expectations as well as to the underlying research questions. Most of the questionnaires were written questionnaires - as in this case - with the exception of the computer-based questionnaire of Dominitz and Manski (see 1994a, 1994b, 1996, 1997 and also Dominitz 1998). Especially the older studies (Smith and Powell 1990 or Blau and Ferber 1991) tried to find out how good students could predict the current wage level of different worker categories. The study of Betts (1996) kept the tradition, insofar as students were asked to predict the wage level of different groups of graduates and different points in time of their working life. Dominitz and Manski (1996), as well as Wolter (2000) in its replication of the US study, used different scenarios in which students were asked to predict their own (future) wage level as well as the wage level of an average person with the same characteristics (educational level, age, gender). Additionally these studies tried to elicit the individual uncertainties about wage distributions, instead of only asking for point estimates. Whereas the cited studies had to compare their survey data with actual cross sectional wage data in order to get a picture of the "accuracy" of the students' responses, the next two studies applied a different method. Webbink and Hartog (2000) used the Dutch longitudinal "Scholar" project in order to ask students for personal predications of starting salaries and compared them with the actual starting salaries the students got after graduation. Caravajal et al. (2000) used a small sample of students in Florida to predict salaries of graduates, which they compared with data of actual graduates of the same school participating in the same survey. Brunello et al. (2001), finally, used a written

\footnotetext{
${ }^{1}$ For more information see www.etla.fi/PURE
} 
survey similar to the one of Betts (1996) but asked students about personal expectations regarding salaries for two scenarios (University degree and University entrance degree) and two points of time in their professional biography (time of graduation and ten years later).

Due to the differences in methodology and the purposes of the studies, the results are difficult to compare. We will therefore make the necessary references in the present paper.

\section{Purpose}

Most papers in the past have analysed very specific categories of students, in most cases students of economics or business administration. Additionally most studies used only students from one school or University and some of the studies had rather small samples. The main purpose of this paper is to overcome some of the shortcomings of the existing papers by analysing whether there are significant differences in expectations between students of different faculties and disciplines when using a large sample of students of more than one University or school. Contrary to the existing literature we do not limit ourselves to point estimates of wages or wage gains in a very short period of an individual work biography but extend our analysis in the second part of the present paper by attempting to construct real rates of return to education. We then analyse the determinants of differences in the expected rates of return to education.

\section{The data}

The data collection was done in the winter term of the academic year 1999/2000 at the Universities of Berne and Zurich. These two universities have a total of some 30'000 students enrolled. In order to get comparable data the same two-page questionnaire was distributed as in all other countries of the project (see Brunello et al. 2001 for the detailed questionnaire) and adapted to the different terminology in Switzerland. The questionnaire asked for personal information (socio-economic background), information on the study behaviour, wage expectations with two different scenarios, questions related to sources of wage information, costs of study and included a little test to elicit individual time preferences. The data was collected according to following procedure: Courses in different fields of study were selected randomly and lecturers asked for permission to use their course for administering the questionnaire. Once this permission was given, the questionnaires were distributed. The rate of participation was $100 \%$ (no selection problems due to non-responses) and 1'133 questionnaires were returned ( $54 \%$ of the questionnaires came from the University of Berne). Due to higher difficulties to get permission to run the survey in non-economic faculties, there is an oversampling of economics students $(60,8 \%)$ in the survey. $16,2 \%$ were law students, $8,7 \%$ studied human \& social sciences, $8,3 \%$ medicine, $4,5 \%$ technical, natural \& computer sciences, the remaining students $(1,5 \%)$ could not be attributed to the faculties mentioned. The high proportion of economics students provoked also an oversampling of men (roughly two thirds of the interviewees). The majority of students $(84 \%)$ were in the first semester of their studies (16\% started before 1999). The raw data was screened for outliers, missing data and inconsistent or illogical data, which resulted in a considerable reduction of the questionnaires finally analysed (depending on the use, between 25 and $40 \%$ of the questionnaires had to be dropped, thus the written questionnaire resulted in a much greater waste of information 
than comparable surveys using computer based survey methods). Even though all reductions were tested, none resulted in a significant change in the means of the data and all reduced the standard deviations, therefore it is fair to speak of "robust" data.

\section{Results}

Every individual had to make four predictions about salaries. The first two estimates concerned monthly entry salaries after having obtained a) a University Entrance Degree (UED) and b) completed University (UNI). Then they had to predict the wage rise in the first ten years of work for both educational levels, which meant monthly wages at the age of about 30 (UED) and 35 (UNI).

A first descriptive analysis of the data shows that the heterogeneity of the sampled data is somewhat larger than in the Swiss study of Wolter (2000) but smaller than in the US studies of reference (Betts 1996 and Dominitz and Manski 1996). The standard deviation of expected salaries amounts to some $24 \%$ of the mean for the starting salary after graduation from University (Wolter 2000: 20\%; Betts 1996: 28\%). Brunello et al. (2001) argue that the measured heterogeneity of expectations is larger than the actual observed spread of wages in the labour market. While this is also true for the Swiss data sampled in this study, their result is not comparable with the results of Wolter (2000), who found that the test persons in his study underestimated wage inequality in Switzerland. In the latter study the real earnings distribution was compared with the subjective uncertainty about earnings (individual expectations of the wage distribution) and not to inter-individual differences in expectations.

\section{Point estimates}

Every test person had to give information about four data points, which can be compared with actual wage data observed on the labour market. When comparing the expectations with the actual wage data several problems arise:

a) There are different possibilities to measure the deviations of expectations from actual wage data. We will present our results in the form of the mean signed error and also in the form of the absolute (mean signed) error.

b) Actual wage data can be collected from different sources. For all wages we use the Swiss Labour Force Survey (SLFS). This survey has the advantage of giving us wages for all ages of the workers but does not allow differentiation according to fields of study. Additionally, the number of people with a specific degree at a certain age is rather small in the SLFS and the reliability of the data can therefore be questioned. In order to have more detailed information we therefore also use the Swiss Graduate Survey (Diem 2000) for the time of graduation from University.

c) Comparisons with actual wage data do not reflect the "accuracy" of expectations. We can only test the extent to which student expectations differ from the current wage structure. We also abstract inflation and suppose, as Manski (1993, p. 49), that students form their expectations "in the manner of practising econometricians" and do not consider inflation when forming their expectations. 
When calculating the mean signed error and comparing expectations with the SLFS data, we find that all students significantly overestimated their wages at the time of graduation from University and that only their wage expectations in the case of the UED are accurate (always compared with actual wage data). After ten years of professional experience students tend to underestimate significantly the salaries they would obtain with an UED and still significantly overestimate the salaries they earn with a University diploma. In other words students overestimate significantly the premium they will get for a University diploma by overestimating both the difference between the absolute wage levels of UED and UNI and the increase in wages in the first ten years of professional experience (see also Brunello et al. 2001, table 4\&5).

Comparing the expectations with data from the Graduate Survey 1999 (Diem 2000), we find that at the time of graduation from University, students of economics and medicine have similar expectations to the wages observed in the Survey, while students of human \& social sciences as well as of natural, technical \& computer sciences expect wages that are significantly higher than those reported in the Graduate Survey. Law students are a particular case, since only part of them really enters the labour market after graduation. Those pursuing a career as a lawyer have to complete different spells at courts and in law firms. During these two years they earn, on average, less than one third of the salary their colleagues entering the labour market directly. The expectations reported in the survey are a mix of both cases and therefore difficult to interpret.

The mean signed error naturally obliterates part of the information. The accuracy of students beliefs is therefore better measured with the absolute (mean signed) error $\left(a e_{i}\right)$, wherein overestimates and underestimates do not cancel each other out. By specification of the absolute value of the percentage wage error we applied the logarithmic error, based on the same arguments as Betts ${ }^{\text {b }}$.

$$
a e_{i}=\ln \left(\left|\frac{\left(w_{i}^{\text {exp }}-w_{i}^{\text {actual }}\right) \cdot 100}{w_{i}^{\text {actual }}}\right|\right) \quad \mathrm{i}=1-\mathrm{n}
$$

Table 1

Absolute mean signed error $\left(a e_{i}\right)$

\begin{tabular}{lccc}
\hline \hline & Full group & Men & Women \\
\hline \hline Graduate salary UED & 0.991 & 0.985 & 1.002 \\
Graduate salary UNI & 0.975 & 0.993 & 0.937 \\
Salary UED after 10 years of professional exp. & 1.212 & 1.204 & 1.231 \\
Salary UNI after 10 years of professional exp. & 1.286 & 1.329 & 1.189 \\
\hline \hline
\end{tabular}

In table 1 we present the absolute error; the closer the values are to 1 , the smaller are the deviations of expectations from actual wages. The results can only be interpreted qualitatively but clearly show that

${ }^{2}$ „, The log absolute error is used as the dependent variable since the absolute values themselves are positive, which would have rendered the normality assumption used for inference in OLS highly untenable.,, Betts (1996, p. 42). In the case that 
expectations are much closer to actual wages at the time of graduation and that the deviations from the current labour market data occurs when predicting the increase of salaries in the first ten years of professional experience.

Table 2

OLS regression on "absolute mean signed error"

\begin{tabular}{|c|c|c|c|c|}
\hline \multirow[t]{2}{*}{ Independent variables } & \multicolumn{2}{|c|}{ UED } & \multicolumn{2}{|c|}{ UNI } \\
\hline & $\mathrm{t}_{0}$ & $\mathrm{t}_{10}$ & $\mathrm{t}_{0}$ & $\mathrm{t}_{10}$ \\
\hline Constant & 1.1058* & $1.2709 *$ & -0.1273 & $1.0122 *$ \\
\hline \multicolumn{5}{|l|}{ Sociodemographic characteristics } \\
\hline Women & -0.0065 & 0.0233 & 0.0059 & $-0.1214 *$ \\
\hline Age & 0.0021 & -0.0017 & 0.0085 & 0.0057 \\
\hline Father with University degree & 0.0499 & 0.0412 & -0.0247 & 0.0031 \\
\hline Mother with University degree & -0.0365 & 0.0300 & 0.1283 & -0.0060 \\
\hline In the same field of study as father & -0.0162 & $0.1387 *$ & 0.0065 & -0.1023 \\
\hline $\begin{array}{l}\text { In the same field of study as mother } \\
\text { Education }\end{array}$ & 0.1570 & 0.1535 & -0.4795 & 0.0637 \\
\hline University of Berne (dummy) & -0.0312 & -0.0093 & 0.0679 & -0.0734 \\
\hline Started University before 1998 & $-0.1439 * *$ & 0.0475 & -0.1585 & -0.1015 \\
\hline Started University in 1998 & 0.1135 & -0.1039 & 0.0089 & -0.0464 \\
\hline Higher than average study perf. & 0.0506 & -0.0194 & -0.0890 & 0.0675 \\
\hline Works besides studying & -0.0036 & 0.0111 & 0.0314 & 0.0036 \\
\hline Job perspective after graduation & $-0.0575 * *$ & -0.0248 & $0.1951 *$ & 0.0561 \\
\hline Relative job perspective (UNI/UED) & 0.0050 & 0.0129 & 0.0512 & -0.0055 \\
\hline \multicolumn{5}{|l|}{$\begin{array}{l}\text { Field of study (economics as } \\
\text { reference category) }\end{array}$} \\
\hline Social \& human sciences & -0.0647 & $0.1533 * *$ & 0.0512 & -0.0618 \\
\hline Law & -0.0615 & 0.0593 & -0.1719 & -0.0681 \\
\hline Medicine & $0.1952 *$ & -0.0017 & -0.2066 & 0.1392 \\
\hline Natural, technical \& computer sc. & -0.0035 & 0.0911 & 0.0357 & 0.0188 \\
\hline Other & 0.0732 & $0.1663 * *$ & -0.0349 & -0.2544 \\
\hline \multicolumn{5}{|l|}{ Sources of information } \\
\hline University career centre & 0.0038 & $0.0979 * *$ & -0.0237 & 0.0488 \\
\hline Friends \& Colleagues & -0.0064 & -0.0616 & -0.0264 & -0.0142 \\
\hline Daily and weekly print media & -0.0141 & -0.0218 & -0.0291 & -0.0180 \\
\hline University publications & $0.0100 * *$ & 0.0172 & -0.0629 & 0.0094 \\
\hline Specialised salary reports & $0.2063 * *$ & -0.0810 & $0.3176 * *$ & 0.1425 \\
\hline No information consulted & 0.1075 & -0.0288 & -0.0050 & -0.0081 \\
\hline Number of observations & 851 & 773 & 840 & 784 \\
\hline Mean Dependent Variable & 1.00 & 1.20 & 0.98 & 1.28 \\
\hline Adjusted $\mathrm{R}^{2}$ & 0.024 & 0.018 & 0.023 & 0.030 \\
\hline
\end{tabular}

Significant variables are in bold letters and with asterisks standing for the $1 \%$ significance $(*)$ and $5 \%$ significance $(* *)$ respectively. White Heteroskedasticity-Consistent Standard Error \& Covariance.

expected salaries $=$ actual salaries, the log would be impossible. As this was never the case, we were able to apply the above formula. 
In table 2 we show a regression, as in Wolter (2000, p. 63), to check whether or not students with specific characteristics have significantly larger or smaller deviations from the actual wages observed on the labour market.

Four types of variables are tested as explanatory magnitudes: (1) Sociodemographic characteristics, (2) study behaviour, (3) choice of field of study and (4) sources of information about salaries. $t_{0}$ represents the absolute error of expectations at the time of graduation, $\mathrm{t}_{10}$ the absolute error after ten years of professional experience.

The explanatory power of all categories of independent variables is rather low in general. As already stated in Wolter (2000), the low $\mathrm{R}^{2}$ values indicate that deviations from actual wages can not be explained by single characteristics or group effects. Sociodemographic factors do not explain deviations from the current wage levels, except for women in one case and for students studying in the same field as their father. Women tend to be more cautious regarding the increase of salaries in the first ten years of professional experience, whereas men tend to be - compared with the actual wage level - overly optimistic.

Concerning educational behaviour, we find that the fact that some students work besides studying and therefore have a higher exposure to the labour market has no effect on the $a e_{i}$. Students who started their studies before 1998 have smaller $a e_{i}$ when expecting UED salaries but no significant difference when it comes to UNI salaries. Students who believe to have good job perspectives after graduating have smaller $a e_{i}$ for UED salaries at the time of graduation but tend to have higher expectations and therefore a higher $a e_{i}$ when it comes to starting salaries after graduation from University.

Differentiation according to fields of study shows that in some but not all cases students have larger $a e_{i}$ than students of economics, when it comes to predict salary levels of UED graduates. In respect to UNI salaries, however, there are no significant differences in the $a e_{i}$.

Furthermore, students indicating that they used specific sources of information about salaries had, contrary to what one might expect, rather larger deviations from the current wage level than those who did not consult such sources. In the case of specialised salary reports, students having had access to such studies had either (in the case of UNI-salaries) higher expectations or (in the case of UED-starting salaries) a higher variance in expectations, resulting in larger absolute mean signed errors. It has to be noted, however, that the largest differences do not concern the salaries of University graduates but UED starting salaries, for which only little public information exists.

Considering all four categories of independent variables, the only true surprise seems to be the non-significance of the salary-information consulting behaviour of students and of the educational background of parents. Better informed students or students with easier access to information on salaries do not seem to have expectations that are closer to the current average than those who do not possess these advantages.

\section{Rates of Return to Education}

In empirical applications of the human capital theory simple wage differentials between a lower and a higher educational level are sometimes taken as the best proxy for rates of return to education (see e.g. Wilson et al. 2000 or Lauer 2000). We know however, that in reality true rates of return are influenced by a number of factors 
that could differ between students and groups of students. Individual time preferences may differ as well as direct costs of studying, the length of study or the timing of study. Therefore differences in salary expectations alone may not be an adequate substitute for rates of return expectations. We test in the following, whether differences in expected rates of return to education depend on other factors than differences in salary expectations.

Although the questionnaire provided most of the data wanted, one important element, namely the expected salaries beyond the first ten years of professional life, was missing. In order to calculate rates of return to education, we had to construct these years artificially. Firstly, we assumed that between graduation and ten years later the salaries increased linearly. Secondly, we calculated an extended Mincerian wage equation with data from the SLFS as follows, for men and women separately:

$$
\operatorname{Ln} w_{i}=\alpha+\beta_{1} S_{i}+\beta_{2} \operatorname{Exp}^{*} S_{i}+\beta_{3} \operatorname{Exp}^{2} * S_{i}+\beta_{4} X_{i}+\beta_{5} \operatorname{Exp}_{i}+\beta_{6} \operatorname{Exp}_{i}^{2}+\varepsilon_{i}
$$

$S$ is a dummy for the school level, $X$ a vector for control variables and $\operatorname{Exp}$ stands for experience and $\operatorname{Exp}^{2}$ for experience squared and $\varepsilon_{i}$ for the error term. Contrary to traditional Mincer-equation we also estimated the values of an interaction variable $\left(\operatorname{Exp}^{*} S_{i}\right)$ of school level and experience and experience squared. These two variables were then used to calculate school type specific individual earnings profiles. The individual earnings profiles had the following components: a) they started either at the age of 20 for UED ( $t$ ) or at the expected age of graduation (for UNI) $\left(S_{U N I}\right)$ with the expected wage and b) continued for the next ten years at the expected rate of wage increase, c) continued after that point with an annual increase calculated with the help of equation 2 and stopped for all individuals at the age of $65(\mathrm{P})$ (official age of retirement in Switzerland). The individual earnings profiles were inserted in a type of cost-benefit model (see e.g. Wolter and Weber 1999) of the following type to calculate the net present value (NPV) of a University study:

$$
N P V_{U N I i}=\sum_{t=S_{U N I}+1}^{P}\left(W_{U N I}-W_{U E D}\right)_{t} *(1+t)^{-t}-\sum_{t=1}^{S_{U N I}}\left(C_{U N I}+W_{U E D}\right)_{t} *(1+t)^{-t}
$$

The direct costs of study $\left(C_{U N I}\right)$ were also individual expected values taken from the questionnaire. Discounting was done at two different rates $(i)$. In the first calculation we used a $5 \%$ discount rate for all individuals, in the second calculation the individual discount rate resulting from the questionnaire.

In the questionnaire students were asked whether they would be better or worse off if they received a gift of 1020 Euros in one year than a colleague who receives 1000 Euros now. The amount given to them in one year was subsequently augmented step by step to a final amount of 1120 Euro. The point where students switched from "worse off" to "better off" was interpreted as the individual time preference. The way questions were asked allowed for two corner solutions in the case that students felt that they were always better off or always worse off. This leads to a potential underestimation of the mean of the reported discount rate. The mean is also significantly 
lower than values found in comparable studies (see e.g. Oosterbeek and van Ophem 2000). Some students switched more than once - behaviour that is not rational - and were therefore eliminated from the data set.

Table 3

Time preference - individual discount rates

\begin{tabular}{lcc}
\hline \hline Group & Discount rate & t-value* \\
\hline \hline Economics & 7.886 & -2.005 \\
Social \& human sciences & 6.767 & -0.213 \\
Law & 7.772 & -0.528 \\
Medicine & 7.618 & -2.223 \\
Natural, technical \& computer sciences & 6.260 & -2.511 \\
Women & 7.120 & \\
\hline \hline
\end{tabular}

*t-value at 5\% level of significance and economics students as reference group; men are the reference group for women with a discount rate of 7.888 .

With the help of the net present value we finally calçulated a form of relative income advantage over the life time, called relative rate of return subsequently $(\mathrm{RRE})^{3}$ :

$$
R R E_{i}=\left(\frac{N P V_{U N I i}}{\sum_{t=1}^{P}\left(W_{U E D}\right)_{t} *(1+t)^{-t}}\right) * 100-100
$$

$\operatorname{RRE}(1)$ was calculated on the base of the uniform discount rate of 5\% and $\operatorname{REE}(2)$ with the individual discount rate. This relative rate of return to education is not directly comparable to similar calculations (e.g. Wolter and Weber 1999 or Weber et al. 2001) because of some limitations in the factors that were taken into account and also because the expected wages are gross wages before taxes. Therefore we limit ourselves to the analysis of determinants of differences in the expected rates of return to education. The results are presented in table 4.

The set of explanatory variables is the same used in the calculations presented in table 2 , with the addition of a variable on smoking behaviour. Some researchers use smoking habits as an indicator for individual time preferences (see e.g. Festerer and Winter-Ebmer 2000). We tested whether the inclusion of this alternative measure for time preference had an additional explanatory value besides the time preferences used in our model. According to our results the variable was never significant. The interpretation of the results in table 4 is done according to the categories of independent variables:

3 Note that the relative advantage in life income that was calculated here is not directly comparable to a normal rate of return calculation but that our decision to take the life income advantage instead of the internal rate of return does not affect the calculations presented in table 4 . 
Table 4

OLS regression on "rates of return to education" (RRE)

\begin{tabular}{|c|c|c|c|c|}
\hline \multirow[t]{2}{*}{ Independent variables } & \multicolumn{2}{|c|}{ RRE (1) } & \multicolumn{2}{|c|}{ RRE (2) } \\
\hline & Coef. & S.D. & Coef. & S.D. \\
\hline Constant & 13.83 & 20.83 & 1.987 & 20.99 \\
\hline \multicolumn{5}{|l|}{ Sociodemographic characteristics } \\
\hline Women & -4.29 & 4.23 & 0.75 & 3.97 \\
\hline Age & $-2.84 *$ & 0.65 & $-1.61 * *$ & 0.69 \\
\hline Father with University degree & 4.22 & 3.92 & 2.90 & 4.45 \\
\hline Mother with University degree & 6.34 & 7.05 & 3.16 & 6.45 \\
\hline In the same field of study as father & 8.14 & 7.90 & 13.57 & 8.38 \\
\hline $\begin{array}{l}\text { In the same field of study as mother } \\
\text { Education }\end{array}$ & -7.87 & 17.78 & -17.84 & 15.05 \\
\hline University of Berne (dummy) & $9.37 * *$ & 4.56 & $9.69 * *$ & 4.62 \\
\hline Started University before 1998 & $-22.63^{*}$ & 6.52 & $-21.57 *$ & 7.59 \\
\hline Started University in 1998 & -3.95 & 6.25 & -0.27 & 7.56 \\
\hline Higher than average study perf. & $12.98 *$ & 3.71 & $10.35 * *$ & 4.16 \\
\hline Works besides studying & -2.96 & 3.64 & -5.36 & 4.10 \\
\hline Job perspective after graduation & $10.13 *$ & 3.39 & 2.92 & 2.93 \\
\hline $\begin{array}{l}\text { Relative job perspective (UNI/UED) } \\
\text { Field of study (economics as } \\
\text { reference category) }\end{array}$ & $10.79 *$ & 2.19 & $8.36 *$ & 2.28 \\
\hline Social \& human sciences & 3.26 & 11.60 & -10.45 & 8.70 \\
\hline Law & $-25.00 *$ & 6.14 & $-27.02 * *$ & 11.18 \\
\hline Medicine & -0.71 & 8.89 & 18.30 & 9.37 \\
\hline Natural, technical \& computer sc. & 2.95 & 9.54 & 0.30 & 10.12 \\
\hline $\begin{array}{l}\text { Other } \\
\text { Sources of information }\end{array}$ & 2.05 & 7.28 & -10.99 & 10.42 \\
\hline University career centre & 8.50 & 8.23 & 7.47 & 10.06 \\
\hline Friends \& Colleagues & 0.75 & 3.96 & 1.22 & 4.06 \\
\hline Daily and weekly print media & -2.08 & 3.97 & -3.53 & 4.16 \\
\hline University publications & 0.51 & 5.63 & 0.94 & 6.70 \\
\hline Specialised salary reports & 16.45 & 11.06 & 9.99 & 16.71 \\
\hline $\begin{array}{l}\text { No information consulted } \\
\text { Time preference }\end{array}$ & 10.01 & 5.87 & $13.31 * *$ & 6.70 \\
\hline Smoking at the age of $17 / 18$ & -4.17 & 4.44 & 3.92 & 4.03 \\
\hline Number of observations & 618 & & 481 & \\
\hline Mean Dependent Variable & 37.58 & & 25.04 & \\
\hline Adjusted $\mathrm{R}^{2}$ & 0.15 & & 0.10 & \\
\hline
\end{tabular}

Significant variables are in bold letters and with asterisks standing for the $1 \%$ significance $(*)$ and $5 \%$ significance $(* *)$ respectively. White Heteroskedasticity-Consistent Standard Error \& Covariance.

Sociodemographic characteristics: Apart from the age of the students, no other factor seems to have an influence on the expected size of the rates of return to education. The factor age is rather an artefact of the way the RRE were calculated than really a difference in expected RRE's. Older students have a shorter period to 
compensate for the investments and therefore have smaller RRE's. The significant negative effect therefore only proves that older students apparently do not expect higher wages that would compensate for the shorter period of earnings. Women have significantly lower wage and wage gain expectations resulting in a smaller, although not significant, expected RRE(1). At the same time they have significantly lower expected discount rates (see table 3 ), which leads to a positive sign (also non-significant) of the coefficient in the $\operatorname{RRE}(2)$ equation taking the individual time preferences into account.

Education: Students studying at the University of Berne have higher expected RRE's than students of the University of Zurich. That structural difference is difficult to explain but shows the necessity to include more than one school in a survey. Older students have significantly lower RRE's than "fresh students" in their first semester. Students, who expect to have very good job perspectives after graduation have a higher RRE(1) but not in the case of $\operatorname{RRE}(2)$, therefore they must also have a higher time preference, maybe because they are more job and labour market oriented. Those expecting better job perspectives after graduation from University relative to the perspectives after the UED have higher RRE's in both cases.

Also significant is the self-evaluation of one's academic performance. Students had to mark their personal academic performance relative to their colleagues on a scale between 1 (very good) and 6 (very poor). The average performance of all students was significantly below 3. This result itself is not surprising as it is a standard observation in psychological (e.g. Lichtenstein and Fischhoff 1977) and economical (e.g. Schmalensee 1976) experiments. More interestingly is the observation that those believing to be better performers also expect to have the positive financial effects associated with their academic superiority. Additionally we find, that - like in other studies (e.g. Wolter 1996), women tend to have a more modest view of their relative performance. Their under-representation in this category could also explain partially the non-significance of the gender dummy. This would mean, that the less optimistic self-perception of women is more important than the fact of their being a woman.

Field of study: Apart from the field of law all other students do not differ significantly in their expectations from students of economics. The "law" effect was already explained in this paper and should not be over interpreted. Interesting is the observation that perhaps against intuition students of social \& human sciences have expectations that are not lower than those of economics students when controlled for other observable differences. At least to factors seem to explain this, firstly, compared to actual wage data, students of this field tend to overestimate their salary perspectives and secondly, even when expecting lower salaries than economists, this is compensated with significantly lower time preferences (see table 3).

Sources of information: Information about salaries does not play a prominent role, with the exception of those cases where no specific sources about salaries were consulted. These students with no specific information about salaries tend to have - at least in the case of $\operatorname{RRE}(2)$ - significantly higher expectations than the rest. 


\section{Conclusions}

This study on salary expectations of students in Switzerland shows that expected wages after graduation at University are rather accurate compared to cross-sectional data from different sources. Significant deviations from actual wages can be observed for law students, students of social \& human sciences and students of natural, technical \& computer sciences, whereas students of economics and medicine come close to actual wages. Expectations of wage gains during the first ten years of professional experience, however, show consistently higher expected gains than actual gains, with women having the lowest degree of overestimation. Consequently the rates of return to education that were constructed on the base of the reported expectations are also higher then conventional results on the base of labour force survey data. However, significantly higher time preferences and other factors reduce somewhat the degree of overestimation.

As in other studies the found degree of heterogeneity of expectations is large and can not be explained by group specific effects or other observable differences between students. Whereas differences in point estimates of wages display the highest degree of individual - non-attributable - differences, the expected rates of return to education can be explained somewhat by perceived job prospects, the self assessment of academic performance and the seniority of students. Women expect significantly lower wages and lower wage gains then men. These expectations are partially justified by actual wage data. There is, however no significant gender effect concerning the expected rate of return to education, which is a consequence of a significantly lower time preference of women and women having a less optimistic self assessment of their academic performance.

The observed differences, both in wage expectations and in time preferences between students of different fields of study as well as the unexplained high degree of heterogeneity of individual expectations show the need for further research. Bigger samples covering more institutions and more fields of study are needed for a better understanding of how students form their expectations about their personal future after graduation. Only with this information we could then better explain and understand individual schooling decisions. 


\section{Literature}

Betts, J.R. (1996), "What do Students know about Wages? Evidence from a Survey of Undergraduates", The Journal of Human Resources, pp. 27-56.

Blau, F. and M. Ferber (1991), "Career Plans and Expectations of Young Women and Men", Journal of Human Resources, pp. 581-607.

Brunello, G., Lucifora, C. and R. Winter-Ebmer (2001), "The Wage Expectations of European College Students", Quaderni dell'Istituto di Economia dell'Impresa e del Lavoro, No.30, Universita' Cattolica del Sacro Cuore, Milan.

Caravajal, M.J., D. Bendana, Bozorgmanesh, M.A. Castillo, K. Pourmasiha, P. Rao and J.A. Torres (2000), "Inter-gender Differentials between College Student's Earnings Expectations and the Experience of Recent Graduates", Economics of Education Review, 19. pp. 229-243.

Diem, M. (2000), "Von der universitären Hochschule ins Berufsleben, Absolventenbefragung 1999", Neuenburg: Bundesamt für Statistik.

Dolton, P.J. and G.H. Makepeace (1990), "The Earnings of Economics Graduates", The Economic Journal, Vol. 100, pp. 237-250.

Dominitz J. and C.F. Manski. (1994a), "Eliciting Student Expectations of the Returns to Schooling", NBER Working Paper. No. 4936.

Dominitz, J. (1998), "Earnings Expectations, Revisions, and Realizations", The Review of Economics, pp. 374388.

Dominitz, J. and C.F. Manski. (1994b), "Using Expectations Data To Study Subjective Income Expectations", NBER Working Paper. No. 4937.

Dominitz, J. and C.F. Manski. (1996), "Eliciting Student Expectations of the Return to Schooling”, The Journal of Human Resources, pp. 1-26.

Dominitz, J. and C.F. Manski. (1997), "Using Expectations Data to Study Subjective Income Expectations", Journal of the American Statistical Association. Vol. 92. No. 439, pp. 855-867.

Festerer, J. and R. Winter-Ebmer (2000), "Smoking, Discount Rates, and Returns to Education", mimeo, University of Linz.

Lauer, C. (2000), "Enrolments in Higher Education in West Germany", Discussion Paper, No. 00-59, ZEW, Mannheim.

Lichtenstein, S. and B. Fischhoff (1977), "Do Those Who Know More Also Know More about How Much They Know, Organizational Behavior and Human Performance, pp. 159-183.

Manski, C.F. (1993), "Adolescent Econometricians: How Do Youth Infer the Returns to Schooling?", in: C.T. Clotfelter \& M. Rothschild (Eds.), Studies of Supply and Demand in Higher Education, Chicago: The University of Chicago Press, pp. 43-60.

McMahon, W.W. (1987), "Expected Rates of Return to Education", in: G. Psacharopoulos (Ed.), Economics of Education, Research and Studies, Oxford: Pergamon Press, pp. 209-223. 
Oosterbeek, H. and H. van Ophem (2000), "Schooling Choices: Preferences, Discount Rates, and Rates of Return”, Empirical Economics, Vol. 25, pp. 15-34.

Schmalensee, R. (1976), ”An Experimental Study of Expectation Formation, Econometrica, Vol. 44, pp.17-41.

Smith, H. and B. Powell. (1990), "Great Expectation: Variations in Income Expectations among College Seniors", Sociology of Education. 63, pp. 194-207.

Webbink, D. and J. Hartog (2000), "Can Students Predict their Starting Salary? Yes!", Scholar Working Paper Series, WP 10/00.

Weber, B.A., Wirz, A.M. and S.C. Wolter (2001), "Switzerland", in: C. Harmon, I. Walker \& N. WestergardNielsen (Eds.), Education and Earnings in Europe, A Cross Country Analysis of the Returns to Education, Cambridge: Edward Elgar Publishing Ltd, forthcoming.

Wilson K., Wolfe B. and R. Haveman R. (2000), "The Role of Expectations in Adolescent Schooling Choices: Do Youths Respond to Economic Incentives?", paper presented at the $15^{\text {th }}$ IIPF conference in Sevilla.

Wolter, S.C. (1996), "Erwartungsbildung in der Oekonomie”, Bern et al.: Haupt Verlag.

Wolter, S.C. (2000), "Wage Expectations: A Comparison of Swiss and US Students”, Kyklos, Vol.53, No.1, pp. 51-69.

Wolter, S.C. and B. A. Weber. (1999), "On the Measurement of Private Rates of Return on Education”. Jahrbücher für Nationalökonomie und Statistik. Vol. 218. No.5\&6, pp. 605-618. 


\section{IZA Discussion Papers}

\begin{tabular}{|c|c|c|c|c|}
\hline No. & Author(s) & Title & Area & Date \\
\hline 357 & $\begin{array}{l}\text { C. Knoppik } \\
\text { T. Beissinger }\end{array}$ & $\begin{array}{l}\text { How Rigid are Nominal Wages? } \\
\text { Evidence and Implications for Germany }\end{array}$ & 1 & 09/01 \\
\hline 358 & $\begin{array}{l}\text { T. Beissinger } \\
\text { O. Buesse }\end{array}$ & $\begin{array}{l}\text { Bismarck versus Beveridge: Which Unemploy- } \\
\text { ment Compensation System is More Prone to } \\
\text { Labor Market Shocks? }\end{array}$ & 3 & 09/01 \\
\hline 359 & M. Pflüger & $\begin{array}{l}\text { A Simple, Analytically Solvable Chamberlinian } \\
\text { Agglomeration Model }\end{array}$ & 2 & 09/01 \\
\hline 360 & $\begin{array}{l}\text { J. Hansen } \\
\text { M. Lofstrom }\end{array}$ & $\begin{array}{l}\text { The Dynamics of Immigrant Welfare and Labor } \\
\text { Market Behvior }\end{array}$ & $1 / 3$ & $09 / 01$ \\
\hline 361 & $\begin{array}{l}\text { M. C. Berger } \\
\text { J. S. Earle } \\
\text { K. Z. Sabirianova }\end{array}$ & $\begin{array}{l}\text { Worker Training in a Restructuring Economy: } \\
\text { Evidence from the Russian Transition }\end{array}$ & 4 & 09/01 \\
\hline 362 & $\begin{array}{l}\text { J. Angrist } \\
\text { V. Lavy }\end{array}$ & $\begin{array}{l}\text { New Evidence on Classroom Computers and } \\
\text { Pupil Learning }\end{array}$ & 6 & 09/01 \\
\hline 363 & $\begin{array}{l}\text { H. Antecol } \\
\text { D. A. Cobb-Clark } \\
\text { S. J. Trejo }\end{array}$ & $\begin{array}{l}\text { Immigration Policy and the Skills of Immigrants } \\
\text { to Australia, Canada, and the United States }\end{array}$ & 2 & 09/01 \\
\hline 364 & $\begin{array}{l}\text { M. Jäntti } \\
\text { S. P. Jenkins }\end{array}$ & $\begin{array}{l}\text { Examining the Impact of Macro-Economic } \\
\text { Conditions on Income Inequality }\end{array}$ & 3 & 09/01 \\
\hline 365 & $\begin{array}{l}\text { H. S. Nielsen } \\
\text { M. Rosholm } \\
\text { N. Smith } \\
\text { L. Husted }\end{array}$ & $\begin{array}{l}\text { Qualifications, Discrimination, or Assimilation? } \\
\text { An Extended Framework for Analysing } \\
\text { Immigrant Wage Gaps }\end{array}$ & 1 & 09/01 \\
\hline 366 & M. C. Regets & $\begin{array}{l}\text { Research and Policy Issues in High-Skilled } \\
\text { International Migration: A Perspective with Data } \\
\text { from the United States }\end{array}$ & $1 / 5$ & 09/01 \\
\hline 367 & C. Dustmann & $\begin{array}{l}\text { Parental Background, Primary to Secondary } \\
\text { School Transitions, and Wages }\end{array}$ & 5 & 09/01 \\
\hline 368 & J. Angrist & $\begin{array}{l}\text { How Do Sex Ratios Affect Marriage and Labor } \\
\text { Markets? Evidence from America's Second } \\
\text { Generation }\end{array}$ & 5 & 09/01 \\
\hline 369 & A. S. Kalwij & $\begin{array}{l}\text { Individuals' Unemployment Durations over the } \\
\text { Business Cycle }\end{array}$ & 3 & 09/01 \\
\hline 370 & A. S. Kalwij & $\begin{array}{l}\text { Individuals' Unemployment Experiences: } \\
\text { Heterogeneity and Business Cycle Effects }\end{array}$ & 3 & 09/01 \\
\hline 371 & $\begin{array}{l}\text { S. C. Wolter } \\
\text { A. Zbinden }\end{array}$ & $\begin{array}{l}\text { Rates of Return to Education: The View of } \\
\text { Students in Switzerland }\end{array}$ & 5 & \\
\hline
\end{tabular}

